\title{
Az alacsony státuszú, szegénységben élő falusi fiatalok immobilitásának okai ${ }^{1}$
}

\author{
CZIBERE IBOLYA ${ }^{2}$
}

\begin{abstract}
ABSZTRAKT
Tanulmányomban a kisfalvakban élő, alacsony iskolázottságú és szegény sorsú fiatalok mobilitásának és mobilitási hajlandóságának hiányát vizsgálom. Arra keresem a választ, hogy a legrosszabb helyzetü fiatalok miért nem költöznek el a falujukból jobb munka- és életlehetőségeket, jobb perspektívákat kínáló térségekbe. A tanulmány kitér a családi életükre és a szülőkhöz füződő viszony értelmezésére is, ezen keresztül a falvakban maradást befolyásoló kötődéseikre. Az elemzés legföbb kérdése, hogy az ezekben az elszegényedett falvakban élő fiatalok immobilitása önkéntes vagy kényszerek által irányított, racionális döntés vagy sodródás eredménye? A feltárt összefüggések szerint az elszegényedett földrajzi környezetben élö falusi fiatalok mobilitásának hiánya nem szabad döntések következménye. Az eredmények szerint egy sodródó, saját életét nem irányító társadalmi csoport, amelynek tagjai nem ismerik a körülöttük lévő tágabb világot, tájékozatlan, függő helyzetü, másoknak kiszolgáltatott, egyszerü reciprocitásra épülő életvilágban élö, és ebben az értelemben kirekesztődött társadalmi csoport.
\end{abstract}

KULCSSZAVAK: szegénység, falusi fiatalok, immobilitás, munkanélküliség, társas kapcsolatok hiánya

\section{ABSTRACT}

\section{Causes for the Lack of Mobility Among Low-Status, Impoverished Rural Youths}

This study explores the lack of mobility and the lack of motivation for mobility among povertystricken youths with low levels of education who live in small villages. I strive to find out why underprivileged young individuals stay in their local village instead of moving to areas with more abundant opportunities and employment. My manuscript also examines their family life and their relationship with their parents, and how those factors could impact their attachment to their village. The main question to analyze is whether young people stay in impoverished rural villages voluntarily or as a result of a lack of choice and a rational decision, or whether they are drifting. My analysis of the data indicates that the lack of mobility among destitute

\footnotetext{
${ }^{1}$ A kutatást az MTA TK Mobilitási Centrum Kiválósági Együttműködési Program támogatta, a kutatás a Debreceni Egyetemen zajlott.

${ }^{2}$ Egyetemi docens, Debreceni Egyetem Szociológia és Szociálpolitika Tanszék, czibere.ibolya@arts. unideb.hu.
} 


\section{TEMATIKUS TANULMÁNYOK - Községekben élő immobil fiatalok}

rural youths is not driven by free decisions. My results suggest that these young people belong to a drifting social group, not in charge of their own fate, unaware of the world beyond their immediate surroundings, uninformed, dependent, vulnerable, living in an environment based on mere reciprocity, and thus, in a sense, they are a marginalized social group.

KEYWORDS: poverty, rural youths, lack of mobility, unemployment, lack of social bonds

\section{Bevezetés}

A fiatalkori életutat 30 éves kor alatt a szociológiai szakirodalmak gyakran a posztadoleszcencia jelenségeként, elkülönült kutatási témaként vizsgálják. E korosztály szociális státuszának, magatartás- és viselkedésszerkezetének jelentős változásai hívták fel a figyelmet a fiatalkori életszakasz kitolódására, a megváltozott viselkedésformákra, valamint a szexuális érettség és az anyagi függetlenség közötti időszak egymástól egyre markánsabb eltávolodására (Vaskovics 2000). A nemzetközi szociológiai irodalmak mindezt vagy a fiatalkor homogén életszakaszának megszűnéseként, vagy a fiatalkor kitolódásaként, mások a fiatalkor és a felnőttkor táguló határvonalaként értelmezték (Vaskovics 2000). A koncepciót a tudományos vitákba Keniston (1968) vezette be, felvetéseként a felnőtté váló fiatalok a pszichológiai kritériumok többségének megfelelnek, de a szociológiai követelményeket nem elégítik ki. Elsősorban a felnőttkort társadalmilag megalapozó tulajdonságok hiányát és a társadalom intézményes szerkezetébe történő beágyazódást tekintette a legfőbb különbségnek a felnőttekhez képest. Meg kell jegyeznünk, hogy egyes szerzők fiatal felnőttként a 21-25 éves korosztályt (Schafers 1989), mások általánosabb értelmezésben a 30 éves kor alatti életszakasz átstrukturálódásának folyamatában értelmezik egy új életszakaszként a posztadoleszcenciát (Vaskovics 2000).

A posztadoleszcens életszakasz elhúzódása, kiszélesedése a társadalom modernizációs jeleként értelmezhető. Vaskovics (2000) álláspontja szerint „[A] posztadoleszcens korban levő fiatalok szignifikánsan azzal jellemezhetők, hogy némely szempontból még a fiatalokhoz, más szempontból azonban már a felnőttekhez tartoznak. Az említett kor társadalmi kompetenciájának társadalomszerkezeti inkonzisztenciájáról van szó, aminek jelentős hatásai vannak az individuális életkonstrukciót illetően." (Vaskovics 2000: 3).

Mivel a társadalom fiatal tagjai ennek folyamatát eltérő időtávokban és különbözően élik meg, vélhetően társadalmi státusztól is függő jelenségként értelmezhetjük. Esetünkben a téma specialitását egyrészt az adja, hogy hátrányos helyzetű, rurális térségekben zajlott a kutatásunk, olyan fiatalok körében, akiknek a szülei is ugyanabban a faluban élnek, másrészt ebben a tanulmányban a posztadoleszcens életkori szakaszban járó, de nem középosztályi miliőben, hanem szegénységben élő fiatalok földrajzi mobilitását befolyásoló tényezőket vizsgáljuk. Körükben nem jellemző a hosszabb képzési idő és a kései munkavállalás miatti felnőtt státusz késleltetett vál- 


\section{TEMATIKUS TANULMÁNYOK - KöZségekben élő immobil fiatalok}

lalása, legalábbis ebben az értelemben nem. Úgy véljük, hogy körükben a nagykorúság elérése és a szociológiai értelemben vett felnőttkor közé nem ékelődik jellemző módon önálló szakaszként a posztadoleszcens életszakasz. Mindez összefügg azzal is, hogy az alacsony iskolai végzettség erőteljesen meghatározza az egyébként is szűkös életlehetőségeket biztosító kistelepüléseken a fiatalok esélyeit, és a magasabb végzettségűekhez képest egyrészt erős versenyhátrányt teremt a posztadoleszcensekkel szemben, másrészt jóval korábbi életkorban szükséges meghozni a felnőtt szerepekkel együtt járó döntéseket (családalapítás, munkavállalás, mobilitás, stb.) a középosztályi fiatalokhoz képest. Mindez erőteljes hatást gyakorolhat a migrációs döntéseikre is.

\section{A kutatás módszerei}

Tanulmányunk célcsoportját azok az alacsony iskolázottságú fiatalok képezik, akik egy-egy kis falu zárt világában élnek, legalább második generációs falusi lakosként. Témánk központi kérdése, hogy „Miért jó a faluban élni?”, amelyet a felkeresett fiataloknak és az ugyanabban a faluban élő szüleiknek is feltettünk. A két korosztály válaszai alapján mutatjuk be azokat a mélyebb összefüggéseket, amelyek jelentős részben magyarázhatják a szegény sorsú falusi fiatalok mobilitásának és mobilitási hajlandóságának hiányát. A megkérdezett, alapfokú végzettségű fiatalok 19-25 év közöttiek, szakmájuk nincs, legfeljebb elkezdett, de be nem fejezett középiskolával rendelkeznek, hasonlóan a szüleik is. Összesen 104 interjút készítettünk, ebből 53-at a fiatalokkal, 51-et a szülőkkel, ezekből az interjúkból választottuk ki és elemeztük az alacsony iskolázottságúakkal és szüleikkel készült interjúkat.

A kutatás során a falvak kiválasztásának egyik fontos szempontja volt, hogy népességszáma ne haladja meg a 2500 főt. Térségi feltételeket nem szabtunk. A kutatás 5 kelet-magyarországi megyét érintett, ezen belül 15 települést. A települések jelentős része komplex programmal fejlesztendő járásokban található hátrányos helyzetü falu (1. ábra).

A települések kiválasztása véletlenszerúen történt, az interjúkat a Debreceni Egyetem szociológus, szociálpolitikus és szociális munka szakos hallgatói készítették a saját falujukban. Az adatfelvételre 2018 őszén került sor.

A vizsgált célcsoport kiválasztásának egyik meghatározó feltétele volt, hogy a szülők is abban a faluban éljenek, ahol a felkeresett fiatalok, amely biztosította, hogy kifejezetten a tősgyökeres falusi népességet vizsgáljuk. Ennek következtében a szülő-gyermek válaszok összevetése az összefüggések átfogó értelmezésére adott lehetőséget.

$\mathrm{Az}$ egyes térségekre jellemző munkaerőpiaci lehetőségekkel kapcsolatban a megkérdezett szülők többségének még voltak emlékei stabil, jól tervezhető munkákról, az alacsony státuszúaknak az agráriumban és ingázással a városokban elérhető 


\section{TEMATIKUS TANULMÁNYOK - Községekben élő immobil fiatalok}

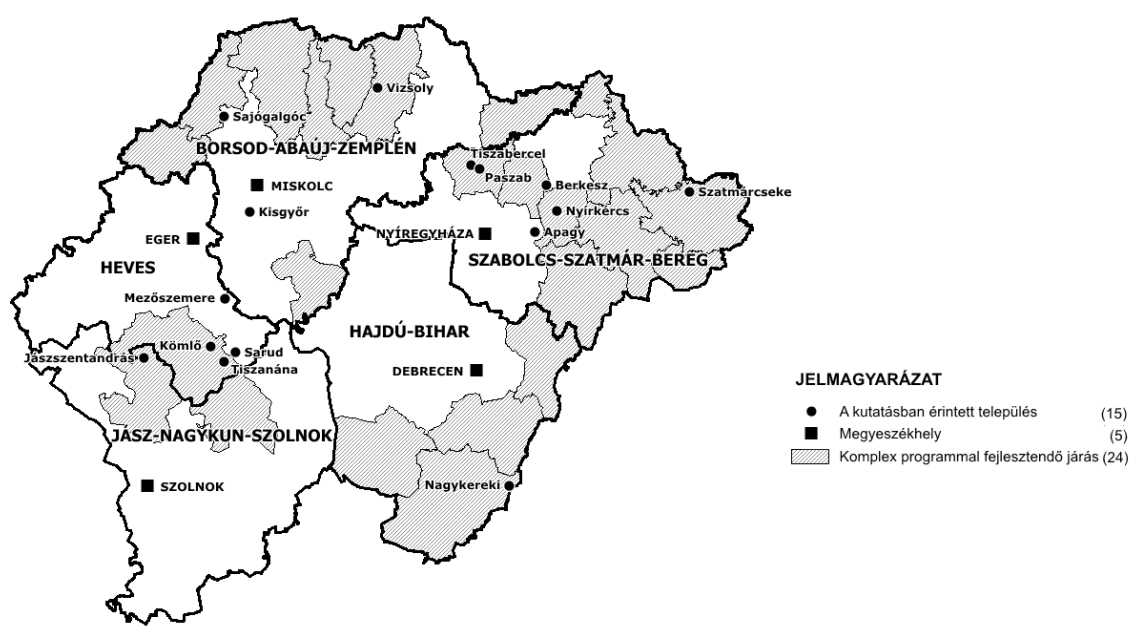

1. ábra: A kutatás helyszínei

Szerkesztette: Balcsók István, 2019

állásokról, amelyek a rendszerváltás után fokozatosan eltűntek, és új megélhetési stratégiák és életszervezési kényszerek léptek a helyükbe.

Az elemzés során arra kerestük a választ, hogy milyen okai vannak annak, hogy a legrosszabb helyzetű, legalacsonyabb státuszú fiatalok a szülők vélhetően romló, de minimum stagnáló helyzete ellenére a falujukban maradtak, milyen lehetőségeket és perspektívákat látnak az immobilitásban, illetve vannak-e demotivációs hatások, amelyek nem teszik lehetővé a jobb feltételeket kínáló térségekbe történő átköltözést vagy munkavállalást. Ehhez elsődlegesen a legalacsonyabb iskolai végzettségű fiatalokkal készült interjúkat elemeztük, amelyeket a szüleik által elmondott információkkal egészítettünk ki és értelmeztünk.

Elemzésünkben törekedtünk arra, hogy a vizsgált kérdésekre adott válaszokhoz megfelelő értelmezési keretet biztosítsunk, ezért nem csupán a munkaerőpiaci helyzetük leírása volt a cél, hanem a családi életük, a szülőkhöz fűződő viszonyaik alapján kívántuk feltárni a kötődéseiket és mobilitásuk hiányának okait. A legfőbb kérdésünk az volt, hogy a legrosszabb helyzetű fiatalok immobilitása önkéntes vagy kényszerek által irányított, illetve racionálisan megfontolt döntésekre alapozott vagy sodródás eredménye?

Az immobilitást térségi-területi szempontok alapján vizsgáltuk. Célcsoportunkban a társadalmi értelemben vett intergenerációs mobilitás is hiányzik, a fiatalok a szüleikhez képest nem státuszváltók, örökölt helyzetükben legfeljebb a szülők hiányzó alapfokú végzettségét lépik túl a 8 osztályos végzettség megszerzésével, illetve a középiskola elkezdése esetén akár 10 osztály elvégzésével, de a félbehagyott tanulmányok miatt az iskolai évek magasabb számának hatása nem érvényesül. 


\section{TEMATIKUS TANULMÁNYOK - Községekben élő immobil fiatalok}

A következőkben a „Hogyan ítéli meg a falun belül a saját helyzetüket? Hasonló-e a többséghez? Ha más, akkor miben más?”, valamint a „Miért jó a faluban élni?” kérdésekre adott válaszok alapján értelmezzük az alacsony státuszú fiatalok immobilitásának okait.

\section{A fiatalok szubjektív státuszhelyzete a falvakban}

A fiatalok élethelyzetében közös jellemző az alacsony iskolázottság, a munkanélküliség és/vagy a közmunkákból és alkalmi munkákból élés, a szegénység vagy még inkább a mélyszegénység. Feltételeztük, hogy a megkérdezett fiatalok ebben a helyzetben szubjektíve kirekesztettséget is megélnek, de az ellenkezőjét tapasztaltuk. Mivel a kutatásunkba kerülő falvak legnagyobb része komplex programmal fejlesztendő, vagyis leghátrányosabb helyzetű település, a népesség jelentős része alacsony életszínvonalon él, negatív értelemben vett társadalmi egyenlőségben (az alacsony életszínvonal egyenlőségében), különösen azokon a településeken, ahol a mintánkba került legszegényebb fiatalok is élnek. Ez azt is jelenti, hogy vannak falvak, amelyekben nem látnak magasabb jóléti szinten élő családokat a megkérdezett fiatalok, illetve többségük kizárólag hasonló helyzetben élő vonatkoztatási csoporttal, hasonló sorsú személyekkel érintkezik, amely erős konformitást eredményez.

A bourdieu-i megközelítésben a társadalmi tér képes életstílusok tereként, vagyis életstíluscsoportok halmazaként, szimbolikusan működni. Ebben az összefüggésben az egyén szubjektív önértelmezése nem különíthető el a társadalmi térben elfoglalt helyétől, melyet a rendelkezésére álló összes társadalmi, gazdasági, kulturális és szimbolikus tőke mennyisége és összetétele határoz meg. Az ebben a térben betöltött pozíciója befolyásolja céljait, vágyait, elvárásait, és meghatározza társadalmilag beágyazódott cselekvéseit (Bourdieu 1985).

A fentiek alapján az interjúalanyok válaszaiból következtethető, hogy a fiatalok és szüleik hasonló módon érzékelik a társadalmi térben elfoglalt helyüket (még inkább a családjukét), és az ehhez kapcsolódó cselekvési esélyeiket és lehetőségeiket is. Helyzetükbe a többségük beletörődött és berendezkedett a napi szintű létbizonytalanságok elhárítására. Alacsony társadalmi pozíciójuk ellenére a válaszok alapján egyértelművé vált, hogy a vizsgált társadalmi térben sem a megkérdezett szegénységben élő szülők, sem a szegénységben élő felnőtt gyermekeik nem érzik kirekesztettnek magukat, sőt, az is szembetűnő, hogy egyöntetűen átlagos vagy csak kissé rosszabb helyzetűnek minősítik családjaikat (de mindnyájan szegénynek tekintik magukat) (1. táblázat). Mivel konkrét kérdés nem kérdezte, nem tudjuk megválaszolni, hogy ténylegesen marginális-e az egyén vagy családja helyzete a falu lakosságán belül. A válaszaik alapján elfogadjuk, hogy szubjektíve integrált társadalmi csoportról van szó. 
www. metszetek.unideb.hu

\section{TEMATIKUS TANULMÁNYOK - Községekben élő immobil fiatalok}

1. táblázat: „Hogyan ítéli meg a falun belül a saját helyzetüket? Hasonló-e a többséghez?”

\begin{tabular}{|c|c|}
\hline Fiatal & Szülő \\
\hline $\begin{array}{l}\text { „Hát mi kicsit szegényebbek vagyunk. Nem } \\
\text { nagyon van megélhetésünk.” (21 éves, férfi, } \\
1 \text { gyermek, szüleivel él) }\end{array}$ & „Átlag család vagyunk, átlag." (szülő) \\
\hline $\begin{array}{l}\text { „Hát szerintem hasonló, nem vagyunk sem } \\
\text { szegényebbek, sem gazdagabbak.”(25 éves, } \\
\text { férfi, egyedülálló, szüleivel él) }\end{array}$ & $\begin{array}{l}\text { „Hát szerintem hasonló lényegébe a helyze- } \\
\text { tünk.” (szülő) }\end{array}$ \\
\hline $\begin{array}{l}\text { „Átlagos, hasonló.” (25 éves, nő, elvált, } 1 \\
\text { gyermek, szüleivel él) }\end{array}$ & $\begin{array}{l}\text { „Hát nem is tudom, nem sok lehetőség van, } \\
\text { kevés ez a munka. Hasonló a többséghez } \\
\text { nagyon.” (szülő) }\end{array}$ \\
\hline $\begin{array}{l}\text { „Hát igazából véleményem szerint hasonló a } \\
\text { többi családhoz. (...) Az anyagi helyzetünk, } \\
\text { az anyagi helyzetünk miatt is. De viszont a } \\
\text { szeretet, a jóság, a tisztelet így meg van min- } \\
\text { den családnál. Szóval én úgy gondolom, hogy } \\
\text { hasonló...” (25 éves, nő, élettársi kapcsolat, } \\
2 \text { gyermek) }\end{array}$ & n.a. \\
\hline \begin{tabular}{|l|} 
„Hát hasonló, szóval hasonló. Vannak nálunk \\
sokkal rosszabb körülmények között élő \\
emberek, vannak, akik jobb körülményekbe \\
élnek. Hát mi egy olyan középkategóriás \\
család vagyunk. Egy kicsit lejjebb, minthogy \\
feljebb, de úgy megvagyunk. De ugyanígy \\
egy átlagos család. (...) Szüleim, azok ugye \\
közmunkások, annyi lehetőség van itt. Meg \\
ugye nem tanultak olyan szorgalmasan, úgy- \\
hogy ez gyümölcs nekik. Úgy hogy viszony- \\
lag, hogy is fogalmazzak szépen, nagyon \\
szolid körülmények között élünk, de élünk.” \\
(23 éves, férfi, egyedülálló, szüleivel él)
\end{tabular} & $\begin{array}{l}\text { „Szerintem jól vagyunk, megfelelő nekünk } \\
\text { minden, nekem jó, nekem tökéletes.” (szülő) }\end{array}$ \\
\hline $\begin{array}{l}\text { „Szerintem a többség is ugyanazt éli, amit } \\
\text { én, én is ugyanazt, amit ők. Ugyanaz megy } \\
\text { nap mint nap.” (21 éves, nő, házas, } 2 \text { gyer- } \\
\text { mek, háztartásbeli) }\end{array}$ & $\begin{array}{l}\text { „Van, akitől jobban állunk, mert vannak, akik } \\
\text { tőlünk sokkal rosszabb helyzetben vannak. } \\
\text { De vannak olyanok is egy páran, akik tőlünk } \\
\text { sokkal jobb helyzetben van. De nem sok } \\
\text { család mondhatja el itt, hogy mindenkinek } \\
\text { van munkája. Nálunk mindenki dolgozik.” } \\
\text { (szülő) }\end{array}$ \\
\hline
\end{tabular}

Forrás: Saját szerkesztés 


\section{TEMATIKUS TANULMÁNYOK - Községekben élő immobil fiatalok}

\section{A társas kapcsolatok szerepe a falusi szegénységben élő fiatalok immobilitásában}

A személyes kapcsolathálózat kiterjedtsége vagy hiánya sajátosan befolyásolja a szegénységben élő fiatalok mobilitását és kötődésüket a faluhoz. Arra kerestük a választ, hogy a fiatalokat körülvevő helyi szolidaritási kapcsolatok, a szolidaritási védőháló milyen mértékben hat az immobilitásra, van-e a kisközösségeken belül a fiatalok számára is erőforrást jelentő támogató hálózat, amely esetleg a mobilitásuk ellen is hat. Azt is vizsgáltuk, hogy saját korosztályuk tagjaihoz milyen sűrü és minőségű kapcsolatokkal kötődnek.

A későbbiekben be fogjuk mutatni, hogy kapcsolati rendszerük, szolidaritási hálójuk, társas támogató rendszerük rendkívül beszűkült, a meglévők pedig leginkább a legszorosabb családi reciprok kapcsolatokra épülnek, ezek is csak a térben egymáshoz legközelebb élőkre irányulnak, olykor ebben az esetben is csupán esetlegesen.

\section{A CSALÁDI ÉS ROKONSÁGI KAPCSOLATOK MOBILITÁST KORLÁTOZÓ HATÁSA A SZEGÉNYSÉGBEN ÉLŐ FIATALOK KÖRÉBEN}

A falun belüli rokonsági kapcsolatok, az erre épülő mikro szolidaritás a szülői családon keresztül a fiatalok kapcsolatrendszerét is megalapozza, kvázi megöröklik a faluban élő szülők kapcsolati tőkéit. A fiatalokat körülvevő legszűkebb, összetartó kapcsolatok homogének, zártak, többségüket a bizalom, a szolidaritás és a reciprocitás jellemzi, és elsősorban családi kötődésűek. Egyértelműen a biztonsági háló szerepét töltik be, és az érzelmi kötődésre alapozódnak. Ugyanakkor a megkérdezett fiatalok esetében mindezek nem kizárólag pozitív tartalmú jellemzők, mert az ilyen típusú kapcsolatok kizárólagosságuk miatt nem segítik a mobilitást, a más társadalmi csoportokkal történő érintkezést és a társadalmi mozgást sem, valójában bezárják a fiatalokat a saját környezetükbe, peremhelyzetük rögzülését eredményezve. Ennek az az oka, hogy hiányoznak a más típusú, pl. az összekötő és az összekapcsoló kapcsolataik, vagyis a meglévők befelé orientáltsága és kifelé zártsága inkább negatív, korlátozó és bezáró erővé válnak, amelyek az ilyen alacsony lélekszámú falvakban élő alacsony társadalmi státuszú egyének és családok számára lehetetlenné teszik, hogy más társadalmi státuszú egyénekkel is kapcsolatba kerülhessenek. A megkérdezett fiatalok válaszai ezt egyértelműen alá is támasztják, a családi kapcsolataik nem segítik minden esetben a boldogulásukat. Ennek egyik oka az, hogy a faluban élő rokonság tagjaival nem tartják rendszeresen a kapcsolatot.

„Hát unokatesómék innen elkerültek Debrecenbe, most kint vannak New Yorkba. Az édes anyukája, most meg nem mondom, merre van, de ő is messze van, 


\section{TEMATIKUS TANULMÁNYOK - Községekben élő immobil fiatalok}

azt tudom. Édesapja is kint külföldön. Ők így innen kiszabadultak, hál' istennek, nekik bejött az élet.” "Úgy nagyapámékkal, meg a nevelt lányával, meg hát tesóm keresztanyjával (tartják a kapcsolatot - sz.), de velük is ritkán.” „Én a kisbolttól tovább nem nagyon járok, nem is nagyon beszélgetek senkivel, szinte nonstop itthon vagyok." (21 éves nö, házas, 2 gyerek)

„Hát barátaim igazából olyan sok nincs, rokonaim sem, a páromnak a szülei, az élettársamnak. - Velük tartod a kapcsolatot? - Hát nagyjából, igazából, ahogy sikerül, hogy is fogalmazzuk. Tartjuk a kapcsolatot persze, csak ugye ott is a páromnak az anyukája és az apukája beteges így sajnos napi szinten nem tudjuk tartani..." (25 éves nö, 2 gyermek, élettársi kapcsolat)

„Rokonaim vannak, barátaim is (a faluban - sz.). Hát a rokonokkal, azért elég felszínes a kapcsolat, szerintem nem olyan mély vagy mit tudom én." (23 éves férfi, egyedülálló)

A már korábban is emlegetett szoros bizalmi alapú, szolidaritásra és reciprocitásra építő zárt családi kapcsolatok túlsúlya is oka lehet azoknak a társadalmilag újratermelt beágyazott cselekvéseknek, amelyek alacsony társadalmi pozícióhoz kapcsolt redukált életcélokat és egyben státuszátörökítést eredményeznek.

„Hát mindennaposak (a kapcsolatok - sz.). Mindennap tartjuk a kapcsolatot a családtagokkal, meg akik itt maradtak." (25 éves férfi, egyedülálló)

„Mindenkivel tartjuk a kapcsolatot, kb. egy utcában lakunk.” (25 éves nö, 2 gyermek, elvált)

\section{A SZÜLŐI HÁZASSÁGI-FÖLDRAJZI MOBILITÁS HATÁSA}

Sajátosan alakul azokban a családokban a szülők, főként a nők kapcsolati hálózata, akik egy másik faluból költöztek a jelenlegi lakóhelyükre, elsősorban párkapcsolatuk vagy házasságuk miatt. Ők azok a betelepülő szülők, akik korábban rokonságuk hátrahagyásával érkeztek a férjeik falujába, és beintegrálódtak azok rokonsági hálózatába. A betelepülések befolyásolják a szülők véleményét és elégedettségüket a falvakkal kapcsolatban. Ezek legfőbb típusa a házasságkötések miatti, főként női mobilitások köre. Azok az anyák érintettek, akik elveszítették szülőhelyükön élő ismerőseikkel a kapcsolataikat, mert a házasságkötésük miatt elköltöztek a saját településükről, és abban a rokonsági és ismerősi hálózatban élnek, amelyet a faluban a házastárs (a férj) kapcsolati rendszere kínál számukra. Ők a falut a férj és a saját 


\section{TEMATIKUS TANULMÁNYOK - Községekben élő immobil fiatalok}

maguk által kialakított kapcsolataikon, főként rokonsági kötődéseiken keresztül ítélik meg, elsősorban befogadottságuk alapján.

„Hát, azért jó (itt élni - sz.), mert én a férjemmel hazajöttem, én budapesti lakos voltam, idevalósi a férjem $N$-be. Hazajöttünk $N$-be és itt alapítottuk meg a családomat, többi gyerekemet. Kettô született Budapesten és itt élünk. A gyerekek szempontjából nekem jó. (...) Szerintem jól vagyunk, megfelelö nekünk minden, nekem jó, nekem tökéletes. (...) Hát itt maradtunk, mert ide telepedtünk le, innen nincs is szándékunk elmenni. (...) Azok is vannak (rokonok), elég sokan. Nagyon jó emberek, a férjem után, nem az én rokonaim. Rendbe van minden. Jól megbeszéljük a dolgokat, ha segíteni kell, segítenek."(nö, 43 éves, házas, 7 gyermek, közmunkás)

Ehhez képest egy másik kategóriába sorolható azoknak a házassági mobilitás miatt betelepülő, de időközben a házasság megromlása miatt magára maradó aszszonyoknak a helyzete, akik, bár sokakat ismernek a faluban, nem érzik jól magukat. Szegénységük megakadályozza őket a költözésben, miközben hiányoznak a kötődést erősítő reciprok családi kapcsolatok.

„Hát, ha őszinte vagyok, én nem jöttem volna ide. Nem is ismertem ezt a falut annak idején. Ez nekem a második házasságom volt, és azaz ember, akivel másodjára összejöttem, akitöl van nekem ez a két gyerekem, az ottan H-ba nem akart lakni, az hozott ide engem. Másképp én nem jöttem volna ide, így maradtam itt $N$-be. (...) Mert szegény vagyok, nincs rá lehetöségem, azért maradtam itt szó szerint. Ha lenne rá lehetőségem, már elmennék innen egy másik faluba, ahol lenne munkalehetöségem vagy jobban segítenek a polgármesteri hivatalnál is, de itt segítséget nem kapok senkitől." (nő, 57 éves, elvált, 2 gyermek, közmunkás)

A későbbiekben bemutatjuk, hogy ezek a „gyökértelenséget” eredményező helyzetek tovább erősítik a fiatalokban a mobilitással szembeni elzárkózást, miközben hozzájárulnak a marginális helyzet fenntartásához.

\section{A BARÁTI ÉS ISMERŐSI KAPCSOLATOK MOBILITÁST GÁTLÓ TÉNYEZŐI A FIATALOK KÖRÉBEN}

Bár a baráti és az ismerősi kapcsolatok alapvetően különböző célokat töltenek be az egyének életében, a vizsgált kistelepüléseken élő legalsó társadalmi csoportba tartozó fiatalok esetében a két kategória között nem tudunk jelentős különbségeket ten- 


\section{TEMATIKUS TANULMÁNYOK - Községekben élő immobil fiatalok}

ni. Arra a kérdésre, hogy „Vannak-e a faluban baráti, rokoni, ismerősi kapcsolatai?”, a barátok és ismerősök említése egyaránt nagyon szórványosan fordult elő a válaszadók körében. Ez azt is jelenti, hogy akár van családi-rokonsági kapcsolata az ehhez a társadalmi csoporthoz tartozó fiataloknak, akár nincs, baráti kapcsolatokat leginkább nem tudnak kiépíteni, illetve a baráti kapcsolatokat többnyire a nagyobb családban élő, egymással rokonságban lévő, hasonló korú fiatalok (sógornők, testvérek) pótolják. Ismerősi kapcsolatok esetén a „haveri kapcsolatok” merültek fel, elsősorban a hasonló sorsú volt osztálytársak köréből. Ebben az esetben tehát sem az erős kötésű baráti viszonyok, sem a gyenge kötésű ismerősi viszonyok nem tudják ellensúlyozni a már korábban említett, mobilitást gátló, zárt családi kapcsolatokat, hiszen ismerőseik vagy egyáltalán nincsenek, vagy a saját státuszukkal azonos csoporthoz tartoznak, vagyis a megkérdezett fiatalok nem képesek a hídszerü, társadalmi rétegeken átívelő ismeretségi kör kiépítésére a személyes viszonyaikban, amely mobilitást segítő tényező lehetne.

„Hát barátaim igazból olyan sok nincs, rokonaim a páromnak a szülei.” (25 éves nö, 2 gyermek, élettársi kapcsolat)

„Baráti kapcsolat van, kint volt külföldön, de most hazajöttek, mert nem úgy sikerült a munka. Óvele tartom szorosabban a kapcsolatot. Vele is nagyon ritkán találkozom." (21 éves nö, házas, 2 gyermek)

„Van egy barátom, ő mindig ide szokott..., vagyis, amikor van egy percnyi időnk, akkor lemegyünk egymásnál, elhülyéskedünk, beszélgetünk. Ó idősebb tőlem, de megértjük egymást szóval... egy a hobbink. (...) Általában összeülünk, hülyéskedünk, beszélgetünk, megosztjuk egymással a gondunk, bajunkat." (25 éves férfi, egyedülálló)

„Nincs barátom, testvéreimmel, sógornőimmel dolgozni járunk el, meg bulizni." (25 éves nö, elvált, 1 gyermek)

„Barátok vagy ismerősök...? Nem, nem nagyon.” (21 éves nő, párkapcsolatban él, nem dolgozik)

„Van egy csomó haverom, akik N-be jártak, akik iskolába jártak velem, egy osztályba. Meg így a faluba, akik olyan fiatalok, mint én. Iszogatunk, bulizunk." (21 éves férfi, párkapcsolatban él, 1 gyermek) 


\section{TEMATIKUS TANULMÁNYOK - Községekben élő immobil fiatalok}

\section{A falvakban maradás elsődleges okai a szegény sorsú fiatalok körében}

A korábbiakban bemutatott alacsony státuszhelyzet, az ehhez illeszkedő szúkös kapcsolati viszonyok ismeretében összefoglaljuk, hogy mindezen hátrányok ellenére milyen előnyöket látnak a fiatalok a faluban maradásra, illetve milyen hatások befolyásolják a mobilitásuk hiányát.

\section{„Ide születtem...”}

Az első típusba azokat a fiatal válaszadókat soroltuk, akik soha nem is gondolkodtak azon, hogy máshol is élhetnének, számukra az odaszületés a legfőbb kapocs a faluval, amely a szegénységükben is védelmező biztonságot nyújt, kiszámítható életteret biztosít. Ezt mint legfőbb előnyt említik, és semmilyen egyéb, sem pozitív, sem negatív jellemzőt nem kapcsolnak a településhez.

„Itt nôtttem fel, azért.” (nö, 25 éves, elvált, gyermekét egyedül neveli)

„Hát, mink itt születtünk, ideszülettünk. Ide vagyunk szokva.” (nö, 21 éves, munkanélküli)

$\mathrm{Az}$ „ide születtem” válaszokból azt is feltételezhetnénk, hogy fontos, érzelmi kötődést erősítő információkat őriznek a fiatalok nem csak a közelmúltból, hanem a szüleik, nagyszüleik múltjából is, valamint a falu életéből. Mégis, arra a kérdésre, hogy tudják-e, hogy régen hová jártak az emberek dolgozni, milyen hagyományos tevékenységek kapcsolódtak a falu életéhez, a fiatalok nem tudtak semmilyen biztos információval szolgálni, csak innen-onnan hallott vélekedéseket fogalmaztak meg általánosságban, bizonytalanul: 'nem tudom, nem hallottam semmit, biztos kapálni jártak, meg paradicsomot szedni, csak hírből hallottam, hogy tsz-be jártak, parasztmunkát végeztek' stb.

A múltra vonatkozó kérdésekre adott válaszokból egyértelművé vált, hogy a falu történetéről semmiféle tudásuk nincs, ugyanúgy, mint ahogyan a közvetlen családtagok néhány évtizeddel ezelőtti munkalehetőségeiről, munka- és egyéb tradícióiról sem őriz a kollektív emlékezet semmilyen információt. Vagyis a 'családtagok nyomdokaiban járás' mint kötődést erősítő tényező nem játszik szerepet az immobilitásban, az 'ide születtem' válaszok nem ehhez kapcsolódnak, és nem is fejezik ki sem az odatartozás büszkeséget, sem a hagyományok és az elődök tiszteletét, stb.

A fiatalok válaszait összevetve saját szüleik válaszaival, az alacsony státuszú családok esetében ismételten a falvak szegénységet újratermelő élet- és normavilágával találkozunk. A szülők emlékei és elmesélt múltbéli tapasztalatai arról tanúskodnak, hogy ők maguk is csak azokra a történésekre emlékeznek, amelyekhez közvetlen élményeik füződnek, és ezek mindegyike a státuszukhoz kapcsolódó, alacsony vég- 


\section{TEMATIKUS TANULMÁNYOK - Községekben élő immobil fiatalok}

zettséget igénylő betanított agrárjellegű munkák világához kötődik. A megélhetés és a jövedelemszerzés az ő életükben is kihívásokkal terhelt volt, az alkalmi és időszakos munkák megszerzésétől függött, akárcsak jelenlegi életükben.

„A mostani időhöz képest sokkal többen dolgoztak, de ugyanúgy, mint a mai világban a mi időnkhöz képest is sokkal többen eljártak napszámba, mint egy hivatalos munkahelyre. (...) Ja és P. környékeire, I., T., G., B. Messzire nem mentek, mert még én is abban az időben tudatlan voltam. Nem voltam vele tisztában, hogy milyen lehetöségeim vannak. (...) Itt (a falujában - sz.) legtöbbször kertészkedtek, meg itt múködött a téglagyár, akkor sokan jártak almát szedni, paprikát, paradicsomot." (nő, 43 éves, 5 gyermek)

Az alacsony iskolai végzettségű szülők, függetlenül attól, hogy életkoruk és családi körülményeik is jelentősen eltér a fiatalokétól, hasonló jellegű válaszokat adtak a 'Miért jó itt lakni?' kérdésre, mint az „ide születtem” válaszokat adó gyermekeik.

„Azért mert én itt születtem és itt maradtam. Azért mert itt születtünk, munkahely végett nem tudunk létesülni, de azért elvagyunk, szeretem ezt a helyet." (nő, 60 éves, 6 osztály, közmunkás)

„Hát én itt születtem, én itt is fogok meghalni, mer én nem szeretnék más faluba. Én szeretnék itt meghalni. A fiam is itt halt meg. Oszt én nem akarnák elmenni innen."(nö, 60 éves, 8 osztály, rokkant nyugdíjas)

„Én úgy maradtam a faluban, hogy én elég fiatalon férjhez mentem és ö... megszületett az első gyermekem 2000 előtt. Úgyhogy ez így idekötött. Ez ide kötött. Itt alapítottam családot, gyermekekkel együtt, úgyhogy igazából már máshol új életet kezdeni á... nem, nem." (nő, 36 éves, 10 osztály, 3 gyermek, legidősebb gyermeke 22 éves)

A nagyon szegény tősgyökeres roma asszony számára azért jó a faluban élni, mert az őt elfogadó környezet létbiztonságot teremt számára, vagyis kizárólag a legalapvetőbb, az életben maradáshoz szükséges fizikai létfeltételek kielégíthetősége alapján ítéli meg a faluját, gyermekei pedig más minták hiányában ezt viszik tovább az „ide születtünk...”válaszokban:

„Hát, mer' mer' rendes a polgármester úr. Senkivel semmi bajom nincs. Hát itten törődnek a... rendesek a tanácsná' is, ha bemegy az ember a polgármesteri hivatalba, rendesen fogadják az embert. Meg hát a nép is jó.” (nő, 60 éves, 8 általános, rokkant nyugdíjas) 


\section{TEMATIKUS TANULMÁNYOK - KöZségekben élő immobil fiatalok}

\section{„Csendes és nyugodt..."}

A fiatal válaszadók másik csoportja a 'Miért jó a faluban élni?' kérdésre egyöntetűen a csendességet és a nyugodtságot emeli ki. Egyikük sem említi, hogy mihez képest, de egyetlen interjúalanyunk sem tud más összefüggésben a falu „jóságáról” nyilatkozni. Az ebbe a kategóriába tartozók, ellentétben az előző válaszkategóriával, pozitív és negatív jellemzőket egyaránt társítanak a falujukhoz.

„Egyrészt, a saját véleményem szerint csendes, nyugodt. Nyilván nincsenek bevásárlóközpontok, stb., de a közelben azért van. Én szeretem azt, ha hazajövök munka után, mit tudom én, lefürdök, iszok egy kávét, eszek és csend van. Eltudok menni bárhova. Nyugalom csend, leginkább ezért. (...) Ez egy átlagos falu, viszonylag rosszabb állapotú falu. Hát, na, sok jó nincs benne, inkább csak negativ értelemben, de ez szerintem egy átlagos falu, csóró falu."(férfi, 23 éves, egyedülálló)

„Csendes, nyugodt - már amikor, az én véleményem szerint tökéletes. Semmi probléma nincsen, nincsenek veszekedések, meg a környezet is jó." (nö, 21 éves, házas, 2 gyermek, háztartásbeli)

„Hát, mert csendes. Sok az ismerős, meg ilyenek. (...) Csendes, jó. Nincsenek olyan sok izék, mint másfele. (...) Igen, jobban ismerek mindenkit."(férfi, 21 éves, 1 gyermek, alkalmi munkákat végez)

„Véleményem szerint, amiért jó itt lenni talán, azért mert csendes, nyugodt. Mindenki ismeri egymást. Igazából az egyik pozitív része."(nő, 25 éves, 2 gyermek, élettársi kapcsolat, közmunkás)

A jövedelmi biztonságot jelentő (alkalmi) munkák lététől is függ, hogy a csendesség és nyugodtság pozitív értékelésú-e, inkább a pihentető környezetet jelenti vagy negatív, inkább a tehetetlenséget és kiszolgáltatottságot erősíti, ha éppen nincs miből megélni.

„Ha van munkalehetöség, akkor jó, ha nincs munkalehetőség, nyilván akkor nem és akkor hiába van csend, de hogyha van munka..." (férfi, 23 éves, egyedülálló)

„Hát figyelj, nem mondanám azt, hogy jó, hanem hogy mondjam... nincs más úgymond, nincs más úgy kilátásban. Szóval így azért vagyok itt P-on, mert muszáj." (25 éves, férfi, egyedülálló, szüleivel él) 


\section{TEMATIKUS TANULMÁNYOK - Községekben élő immobil fiatalok}

„Igazából jót is tudok róla mondani, de rosszat is, mivel, hogy túl messze van, ahhoz, hogy... túl elszigetelt helyen van, ahol az emberek nem tudnak fejlödni és nem is tudnak nagyon kitörni."(nő, 25 éves, 2 gyermek, élettársi kapcsolat, közmunkás)

\section{Nem csendes és nem nyugodt... - a szülők véleménye}

Azok a szülők, akiknek a gyermekei a csendesség és nyugodtság pozitívumait tudták a falujuk jellemzőjeként kiemelni, válaszaikban jóval összetettebb faluképet rajzoltak, mint a gyermekeik, de velük ellentétben egyikük sem értékelte „csendesnek és nyugodtnak" a települést. Sőt, határozottabban megfogalmazott elégedettségeket és elégedetlenségeket említettek, mint gyermekeik, és ezek nagyon szorosan kapcsolódnak a jelenlegi családi kötelmeikhez, a fiatal felnőtt gyermekeik jobb vagy roszszabb helyzetéből fakadó rájuk háruló tartási terhekhez.

A következőkben a szülők gyermekeikkel összefüggő szerepvállalásait, kényszereit vagy kötelmeit tipizáljuk, abból a nézőpontból, hogy a falu megítélése szempontjából milyen helyzetek befolyásolják az elégedettséget és az elégedetlenséget. Bemutatjuk azokat az egymásrautaltságokat, amelyek nem csupán az általunk korábban feltételezett, a fiatalok kényszereit, felelősségeit és végső soron mobilitás-hiányát eredményezik a faluban élő szülők és rokonság felé irányuló felelősségérzet miatt, hanem fordítva is, azokat a szülői felelősségvállalásokat is feltárjuk, amelyek a fiatal felnőtt gyermekekre és azok családjaira irányulnak, és amelyek emiatt a szülők életében is erős (kölcsönös) immobilitást kiváltó hatásnak bizonyulnak.

\subsection{A SZÜLŐK FALUKÉPE ÉS HATÁSUK A FIATAL FELNŐTT GYERMEKEIK ÉLETKÖRÜLMÉNYEIRE}

Ebben az összefüggésben a szülők elégedettségi és elégedetlenségi szintjét erőteljesen befolyásolja a felnőtté váló és helyben maradó gyermekeik sorsa, életkörülményeik, megélhetési biztonságuk. A falusi szegény családokra általában is jellemző az az élethelyzet, hogy a felnőtt gyermekeit kibocsátó szülői család számára sok esetben továbbra is megmarad a hasonlóan rossz helyzetben lévő, közel élő felnőtt gyermekek eltartási vagy támogatási terhe, sőt, általában az azok gyermekeiről (unokák) történő gondoskodás felelőssége is. Míg a fiatalok számára a falusi lét többnyire a szülői közelségből fakadó biztonságot jelenti, addig a szülő részéről egy önfeláldozó, erőn felül vállalt, hosszan elnyúló tartási és támogatási kötelezettséget. 


\title{
TEMATIKUS TANULMÁNYOK - Községekben élő immobil fiatalok
}

\section{A falujukkal elégedetlen szülók}

A falujukkal elégedetlenek kategóriájába azokat a szülőket soroltuk, akik semmilyen pozitív jellemzőt nem tudtak mondani a faluról. Tipikus szereplő pl. az a beteg, gyermekeit egyedül felnevelő anya, aki szegénysége miatt nem taníttathatta a gyermekeit, és aki most a „fél oldalán lebénult” lánya két gyermekét is segít gondozni (aki cserébe eljár közmunkába), és aki megosztja a saját közgyógyellátásának keretét a lányával, hogy az hozzá tudjon jutni a nagyon drága fájdalomcsillapító gyógyszerekhez.

Ebben az esetben tehát a falu „csendessége és nyugodtsága”, ahogy a felnőtt gyermeke fogalmazott, az anya számára a faluval kapcsolatos legfóbb elégedetlenség. A falu nem teremti meg a lehetőséget még arra sem, hogy a mindennapjait létbiztonságban, tervezhetően, az egészségi állapota által megkövetelt szolgáltatásokat biztosítva élje.

\begin{abstract}
„Nekem egyáltalán nem jó itt lakni itten, mert ha nekem lehetöségem lenne rá, én már régen elköltöztem volna. Munkalehetöség nincs, közmunkából élek, amit nagyon kevesellek ötvenháromezer forint, sok a tartozásom, nem tudok megélni abból jóformán. Beteges vagyok, közgyógyon vagyok. Nem azt a gyógyszert válthatom ki, ami nekem kéne, szükséges lenne, mert olyat nem adnak, pénzért adják ki. Nincs más munkalehetőségem, nem járok napszámba, sehova. Egyedül neveltem a két gyermekemet itten. Iskoláztatni, nem nagyon iskoláztattam őket. Befejezték, nem nagyon mentek tovább tanulni, mert nem volt rá lehetôségem." (nő, 57 éves, elvált).
\end{abstract}

Az elégedetlenségek másik típusába azoknak a stabilabb élethelyzetben lévő, kevésbé kiszolgáltatott szülőknek a kritikus véleményeit sorolhatjuk, amelyek a magasabb rendű igények kielégítésének (jobb munkaerőpiaci lehetőségek, szabadidő eltöltési lehetőségek stb.) lehetetlensége miatt fogalmazódtak meg a faluval szemben. Körükben is megjelenik a saját felnőtt gyermekeikkel szemben vállalt felelősségérzet, és bár felmerült az igény a falu elhagyására, azért élnek még a faluban, mert az ugyancsak ott élő, és leginkább tőlük függő fiatal felnőtt gyermekeiket és unokáikat nem szeretnék támasz nélkül magukra hagyni.

„Hát az túlzás, hogy jó itt lakni (nevet), csak a gyerekek miatt vagyunk itt. Nem jó a megélhetés, a körülmények miatt. Nem lehet létesülni ebben a kis faluban semmilyen téren. Nem lehet létesülni, a fiataloknak semmilyen szórakozási, kikapcsolódási lehetőség nincs, mint pl. néhány faluval odébb. Itt nincs semmi. Se az én korosztályomnak, sem a fiataloknak. Munkalehetöség úgyszintén semmi, 2 bolt, ami üzemel, abba lehet dolgozni, ahol én is. Semmi egyéb. Van az iskola, óvoda, de hát az kinek ad munkát? Akinek megvan a képesitése hozzá. A többinek marad a közmunka." (nö, 62 éves, elvált, 1 gyermek, dolgozik) 


\section{TEMATIKUS TANULMÁNYOK - Községekben élő immobil fiatalok}

Vagyis az a csendesség és nyugodtság, amely a fiatalok esetében pozitívumként, kiszámítható biztonságként jelent meg a válaszokban a faluval kapcsolatban többnyire a szülői közelség miatt (még akkor is, ha ez az élethelyzetükhöz igazított redukált igényekre, vágyakra épül), a szülők egy csoportja számára ugyanez fokozódó megélhetési nehézségeket, aránytalan súlyú, a fiatal felnőtt gyermekeik napi szintű létbiztonságáért vállalt felelősséget és terhet jelent.

\section{Mobilitást gátló szélsőséges áldozathozatalok és áldozatvállalások szülők és gyermekeik között}

A mindennapi létbiztonságukért küzdő szegény családok körében az egymásért vállalt felelősség és áldozathozatal mind a szülők, mind a fiatalok életében teremthet szélsőséges helyzeteket, követelhet meg önfeláldozást vagy áldozatvállalást. A fiatalok interjúiból kevésbé, de a szülőkkel készült beszélgetésekből annál inkább értelmezhető összefüggések tárhatók fel, amelyeket a következőkben a szülők által hozott áldozatvállalások és a szülők által gyermekeiktől megkövetelt áldozatvállalások formáin keresztül ismertetünk. A végletesség két szélsőségének példája a pénztelensége miatt (gyermekei szegénysége és támogatása hiányában) börtönbe menő anya, és a saját és kiskorú gyermekei megélhetési biztonsága védelme miatt fiatal felnőtt gyermekét magához láncoló kényszerítő anya esete.

Az első esetben az asszony életében a szegénység miatt halmozódó családi problémák (alkoholista férj, válás, alapfokú végzettségű gyermekek munkanélkülisége, azok korai gyermekvállalása, az unokákról történő gondoskodás terhe, a beteg felnőtt gyermek gyógyszerköltségeinek előteremtése, saját betegsége, stb.) miatt a család számára szükséges jövedelem nem áll rendelkezésre, emiatt egy szabálysértési ügy következményeként a pénzbírság megfizetése helyett kénytelen a börtönt választani, mert pénzügyileg sem a gyermekei, sem más a környezetében nem tudja őt támogatni, hogy megmentse ettől a helyzettől.

„Mert szegény vagyok, nincs rá lehetőségem, azért maradtam itt, szó szerint. Ha lenne rá lehetőségem, már elmennék innen egy másik faluba, ahol lenne munkalehetôségem vagy jobban segítenek a polgármesteri hivatalnál is, de itt segítséget nem kapok senkitöl. Most megyek a börtönbe tíz napra, azt is elmondom. Balesetem lett, amiért nincs a biciklimen lámpa meg fék. Kisebb agyrázkódásom volt, oszt még engem büntettek meg ötvenezer forintra, most megyek be majd tíz napra." (nő, 57 éves, elvált)

Ugyancsak a szegénység következményeként értelmezhető a felnőtt gyermekét magához láncoló szülő típusa. Ezt jól példázza annak a nőnek az esete, aki kívülről, a faluba beházasodó háztartásbeli feleségként, megrokkanó férje miatt eltartói 


\section{TEMATIKUS TANULMÁNYOK - KöZségekben élő immobil fiatalok}

szerepbe kerül. Kiszolgáltatott élethelyzete eredményeként szinte kikényszeríti (kizsarolja) felnőtt fia támogatását, annak magánélete ellehetetlenítése árán is. Bár a 21 éves fia a szomszédos faluba költözött élettársa szüleihez, miután megszületett közös kislányuk (8 hónapos), szülei az apa betegségére való hivatkozással mégis arra kényszerítették, hogy költözzön vissza hozzájuk, hagyja ott a családját, és tartsa el a 3 még kiskorú testvérét, illetve segítse a lábfájdalmaktól szenvedő, munkát nem végző apjának és a közmunkás anyjának a megélhetését. A fiatal férfi elhagyta gyermekét és élettársát, a szülői házban él, alkalmi munkákat vállal a környéken, és a megszerzett jövedelme felét a szülői családjának, a másik felét a saját családjának adja, gyermekét és élettársát hetente látogatja.

„Igen, mert megtudtam, hogy édesapám beteg, oszt így amiatt jöttem vissza. A lába, a lába nagyon fáj neki és nem nagyon tud menni és ezért jöttem vissza inkább. Anyagiakban támogatom őket. Felét ide anyámékhoz viszem, másik felét viszem a kicsinek."(férfi, 21 éves, 8 osztály, 1 gyermek, alkalmi munkák)

\section{A falujukkal elégedett szülók}

A szegénységben élők, de a falujukkal elégedettek jellegzetes csoportja a felnőtté váló gyermekeik önállósodása miatt a helyzetükben javulást megélő szülői csoport. A faluval kapcsolatos elégedettségük alapja az, hogy a gyermekeik keresőképessé válásával (netán elköltözésével) jelentősen csökkent az eltartási terhük, erősödött a megélhetési biztonságuk, enyhült a szegénységük. A fiatalok leválása, vagy jövedelemtermelő képességének növekedése (munkába állása) közvetve és közvetlenül is pozitív hatással van a szülői család szegénységének enyhülésére is. Vagyis, ha a fiatalok helyzete javul, jelentősen javul a kibocsátó szülői család helyzete is, amely befolyásolja a faluhoz történő pozitív viszonyulásukat is.

„Hát én születésem óta itt lakok, és a gyerekek végett maradtunk itten, mert elég hamar estem teherbe és én azóta itt vagyok. Mi amúgy nem itt laktunk volna, hanem I-ban. (...) Lényegébe most, mikor már felnöttek a gyerekek, félig felnöttek, most jöjjünk arra a szintre, hogy valahogy élünk. Jobban élünk ahhoz képest, ahogy régebben éltünk. (...) Hát már a mostani fejemmel én úgy gondolom, nekünk most ért be az a munkánk eredménye, amit mi mindig is el szerettünk volna érni, hogy amit mi szeretünk csinálni, azt csináljuk. A férjem azt csinál, amit ő szeret, a gyermekeim lényegébe, ahogy én nézem, amit akarnak meg tudnak maguknak szerezni, úgyhogy most értünk arra a szintre, hogy amit nekünk eddig hiányzott, az megvan. Én úgy vagyok vele, hogy ha eddig jó volt, akkor már ezután is jó lesz. Ha mennénk is, akkor csak a gyerekek miatt mennénk, de mi így nem." (nö, 43 éves, házas, 5 gyermek, dolgozik) 


\section{TEMATIKUS TANULMÁNYOK - Községekben élő immobil fiatalok}

\section{Összegzés helyett: a falu 'csendessége és nyugodtsága' szimbolikája, és az immobilitás okai a szegénységben élő fiatalok körében}

Eredményeink szerint a megkérdezett szegény sorsú fiatalok körében nem releváns a 'miért maradt?' kérdés, hiszen a megkérdezett alsó társadalmi csoporthoz tartozó fiatalok számára ez soha nem is volt választási lehetőség. A többgenerációs munkanélküliség okozta nehézségek, az alkalmi munkák világa, napjainkban a közmunka világa sem teremti meg a lehetőséget az egyének számára a saját sorsuk fölötti szabad rendelkezéshez. A félelem az ismeretlentől, a ragaszkodás a megszokott, megtanult biztonságot nyújtó környezethez és alkalmazható túlélési stratégiákhoz, fontos kapocs a faluhoz. Az együtt élő családtagok között reciprok elven megosztott jövedelmek, vagy a többek együttéléséből származó előnyök, hogy mindig van olyan családtag, aki éppen képes némi jövedelemre szert tenni, amely megosztható az éppen hiányt szenvedővel, ebből kiszakadni kockázatos, és a tanult tehetetlenséggel terhelve nem is kecsegtet sikerekkel.

A következőkben felsorolásszerűen összefoglaljuk a szegénysorban élő fiatalok által csendesnek és nyugodtnak jellemzett falvak világában megjelenített önképüket, az egyes dimenziókban vizsgált kérdésekre adott válaszaik alapján, amely egyben immobilitásukat megerősítő összetett dimenziórendszerként is értelmezhető.

- Szegénynek vagy átlagos helyzetűnek érzik magukat a falujukban, önmagukat vagy rosszabb helyzetűnek, vagy ugyanolyan rossz helyzetűnek vélik, mint a környezetükben élőket, kirekesztődési élményük nincs.

- Mintaadó személyekkel, tőlük jobb helyzetűekkel nem találkoznak, nem érintkeznek, pozitív értelemben nem emelkednek ki az ott élők köréből, a vonatkoztatási csoporthoz képest frusztrációt nem élnek meg.

- Iskolai kudarcokkal tarkított tanulmányi utakat jártak be, szakmát nem szereztek.

- Szórakozni nem szoktak, ennek a kultúrája nem alakult ki, és igényként sem fejeződik ki, legfeljebb ritkán helyben „iszogatás, bulizás” van, de semmilyen rendszeres szabadidős elfoglaltságuk nincs. Ennek hiánya nem okoz elégedetlenséget.

- A fix munkahellyel nem rendelkezők a falun belül alkalmi munkákat keresnek és vállalnak, ha kell házaknál, elsősorban az idősebbek foglalkoztatják őket a nehezebb fizikai munkákra, de nem mennek távol a falutól.

- Nincs időstruktúra, a kiszámíthatatlan alkalmi munkák világa és a közmunka az egyetlen életszervező tevékenység.

- Nem nagyon ismerik a barátkozás fogalmát, igazi (bizalmas) baráti kapcsolataik nincsenek, kapcsolatrendszerüket főleg az ott élő családtagok jelentik, falun kívüli ismeretségi hálójuk szűkös, vagy nincs is.

- A falun belüli ismertségük leginkább a mások általi beazonosíthatóságukat jelenti, nem a tényleges kapcsolattartást és kommunikációt. 


\section{TEMATIKUS TANULMÁNYOK - KöZségekben élő immobil fiatalok}

- Még soha nem voltak távol a falujuktól (kivéve, aki megpróbált máshol dolgozni a férjével, de nem „bírták” és visszajöttek), akad, aki el sem hagyta még rövid időre sem a faluját, és olyan is, aki csak vásárolni jár át a közeli városba busszal vagy autóval, egyébként nincs hová menniük a falun kívülre. Az új környezet megismerése, a jobb lehetőségek elérése nem alakít ki taszító hatást a falutól.

- Többeknek van olyan mintaadó családtagja, aki elhagyta a falut és vagy külföldön vagy belföldön, de távol a falutól él, dolgozik, ettől függetlenül ezek a minták nem hatnak motiváló erőként a mobilitásukra és a jövőterveikre sem, hiába vélték azt, hogy az elmenőknek „,bejött az élet”.

- A faluban a szülői család ismertségétől függ a fiatalok ismertsége is, saját maguk nem építettek új kapcsolati köröket.

- Nem érzik a faluban központi szereplőnek magukat, mint ahogyan a szülői család sem, nem tudtak említeni semmit, ami a faluban nélkülözhetetlenné, ismertté, népszerűvé vagy keresetté tenné őket.

- Többségük legnagyobb büszkesége a „tisztes szegény-lét”.

- Kisebb-nagyobb helyi konfliktusokról hallani szoktak, de nem nagyon vesznek részt bennük.

- A faluban nem kérnek segítséget, de ők szívesen segítenének, ha valaki hozzájuk fordulna.

- Nem szívesen veszik, ha beleszólnak az életükbe, és ők maguk sem érzik, hogy joguk lenne bárkinek tanácsot adni kérés nélkül a faluban, ezt soha nem is teszik, kivéve, ha nagyon közeli családtagról van szó.

- Semmilyen megoldást nem látnak a változtatásra, néhányuk reménykedik egy valamikori elköltözésben, ugyanakkor a szülők iránt érzett támogatási felelősség és/vagy a szülőktől távoli élet bizonytalansága a tervezés gondolatát sem engedi számukra.

- Nyíltan nem vállalják fel a félelmeiket az ismeretlentől, nem is így értelmezik a mobilitásuk hiányát, azt leginkább rajtuk kívülálló körülményekkel vagy az érzelmi kötődéseikkel magyarázzák.

- Kihívások nincsenek az életükben, semmilyen megmérettetésben, teljesítményörömben nincs részük, a mindennapok megélhetésének biztosítása köti le a figyelmüket.

- Más társadalmi csoportok tagjaival nem találkoznak, nem érintkeznek rendszeresen.

- Sem tudásuk, sem határozott jövőterveik nincsenek a változtatásra, biztonságérzetüket saját zárt világuk állandósága adja.

A fiatalokkal készült interjúkból egy sodródó, a saját életüket nem irányító, sőt, arról mélyebben nem is gondolkodó, a körülöttük lévő világot nem ismerő, tájéko- 


\section{TEMATIKUS TANULMÁNYOK - KöZségekben élő immobil fiatalok}

zatlan, függő helyzetű, kiszolgáltatott, általában egyszerű reciprocitásra épülő életvilág körvonalazódik, ahol a falu zárt közege számukra a bezártság, a biztonság és egyben a kirekesztettség közege is.

\section{Irodalom}

Bourdieu, P. (1985): Identitás és reprezentáció. Szociológiai Figyelő, 1 (7-22).

Keniston, K. (1968): „How community mental health stamped out the riots (196878). Trans Action 5. (21-29).

Vaskovics L. (2000): A posztadoleszcencia szociológiai elmélete. Szociológiai Szemle, 10. (1-16). 